
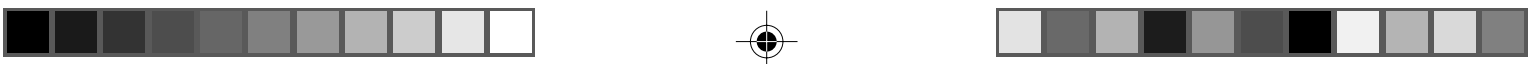

en minoritet, dvs. på 'minoriseringsprocesser'. Positionen som enten minoritet eller majoritet er ikke givet på forhånd; snarere må man i hvert enkelt tilfælde udforske, hvordan personer og grupper både positionerer sig og bliver positioneret af andre og dermed udkrystalliseres som henholdsvis majoritet og minoritet (GitzJohansen). Begrebet 'racialisering' tages op i forbindelse med refleksioner omkring racisme og ligestilling (Horst), ligesom kulturbegrebet og multikulturalisme tages under kritisk behandling (Bundgaard). Resultater fra Socialforskningsinstituttets forløbsundersøgelse af tosprogede børn, som blev indledt i 1996, dokumenterer blandt andet, at disse børn i vid udstrækning reagerer på omstændigheder i deres liv på samme måder som etnisk danske børn (Christensen). En del af et barns opvækst og socialisering foregår i familiens skød, mens en anden del foregår i offentligt regi såsom daginstitutioner og skoler. Hvis man skal forstå tosprogede børns liv, er det dermed afgørende at se på blandt andet familiens socioøkonomiske forhold, og hvilke vilkår en familie har for denne socialisering (Skytte). Det er også vigtigt, at forældre til tosprogede børn inddrages i skole-forældre-samarbejdet, fx via forældremøder. Kommunikationsformen i sådanne møder er imidlertid yderst kulturspecifik og kræver både kulturelle og sproglige kompetencer. Langtfra alle forældre besidder disse kompetencer og færdigheder, hvilket udgør en alvorlig barriere for mange forældres deltagelse i forældre-skole-relationen. Der gives nogle praktiske bud på, hvordan disse barrierer kan mindskes (Agacanoglu).

Bogen henvender sig til en bred målgruppe, herunder mennesker, der i praksis arbejder med multikulturelle problemstillinger. Der er således tale om en indføring i tematikker vedrørende tosprogede børn i Danmark, herunder en præsentation af en række begreber og forståelsesrammer, der kan være nyttige for en større læserkreds i et stadig mere komplekst og mangfoldigt Danmark.

$$
\begin{array}{r}
\text { Yvonne Mørck } \\
\text { Lektor } \\
\text { Institut for Samfund og Globalisering } \\
\text { Roskilde Universitetscenter }
\end{array}
$$

Garbi Schmidt: Muslim i Danmark - muslim i verden. En analyse af muslimske ungdomsforeninger og muslimsk identitet $i$ årene op til Muhammad-krisen. Studier av Interreligiösa relationer 37. Uppsala: Universitetstryckeriet 2007. 145 sider. ISSN 1396-1810. ISBN 978-87-7487-8636. Pris: $160 \mathrm{kr}$.

I skriftet „Etniske minoriteters indflydelseskanaler“, der udkom som led i den nationale magtudredning, konkluderede Ole Hammer og Inger Bruun, at de etniske minoriteters indflydelse på deres egne vilkår og den almindelige samfundsudvikling 

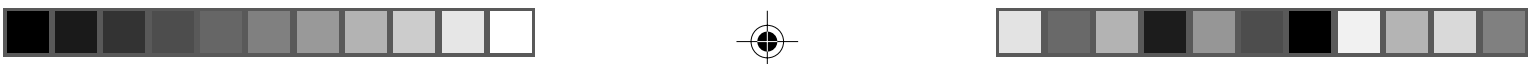

er minimal (Hammer \& Bruun 2000:10). Om det var korrekt dengang, skal vi lade være usagt, men islamolog Garbi Schmidt viser i hvert fald med sin seneste bog, at det ikke gælder længere. Schmidt, der er seniorforsker på SFI - Det Nationale Forskningscenter for Velfærd, giver med bogen Muslim i Danmarkmuslim $i$ verden indblik $\mathrm{i}$, hvordan unge engagerede foreningsaktive muslimer med vidt forskellig etnisk baggrund forholder sig til deres religiøsitet og liv i det danske samfund. Et centralt omdrejningspunkt er, hvordan de foreningsaktive, mere eller mindre succesfuldt, evner at navigere mellem forventninger fra forældre, imamer, medier og myndigheder og er med til at sætte deres præg på den debat om islam og muslimer i det danske samfund, der har hærget det seneste årti.

I sin undersøgelse har Garbi Schmidt anvendt forskellige etnografiske metoder. Således er fremstillingen baseret på 18 interviews foretaget i 2001 og 2002, samt enkelte i 2005. Hovedparten af interviewene dateres til tiden just efter den skelsættende 11. september 2001. Desuden baseres fremstillingen på deltagerobservation under møder og arrangementer iværksat af de muslimske ungdomsforeninger samt på læsning og diskussion af relevante avisartikler, kronikker, læserbreve og internetsider, der enten er skrevet af eller om de unge muslimer, som Schmidts fremstilling kredser om.

Efter en indledende metode- og begrebsafklaring behandler forfatteren i fire afsnit tematikkerne identitet, foreninger, samfundsdebatten og transnationale forbindelser. Første afsnit diskuterer, hvad det indebærer at være muslim her i landet, blandt andet hvordan man i høj grad stilles til ansvar for sin religiøse baggrund. Fra børnehaven over folkeskolen til en eventuel ungdomsuddannelse oplever de unge at skulle stå til regnskab og beredvilligt forklare komplicerede teologiske spørgsmål over for velmenende såvel som skeptiske 'kulturkristne'. I denne subjektiveringsproces bliver man muslim, hvad enten man vil det eller ej. Ens identitet bliver et offentligt anliggende, som det påpeges (s. 37). Følgelig er det også på sin plads, at Schmidt bruger en del sider på at opsummere og perspektivere den evindelige (og noget enerverende) tørklædedebat.

I andet afsnit om de muslimske ungdomsforeninger optegner Schmidt konturerne af det omskiftelige landskab, som muslimske ungdomsforeninger har udgjort det sidste årti. Der gives en behørig introduktion til eksisterende og nedlagte foreninger som FASM (Foreningen Af Studerende Muslimer), MUNIDA(Muslimske Unge i Danmark), Milli Görüs, Hizb ut-Tahrir, Minhaj ul-Qurans ungdomsafdelinger MYL (Muslim Youth League) og WYL (Womens Youth League), Forum for Kritiske Muslimer, MID (Muslimer i Dialog), DFC (Danske Forenede Cybermuslimer), MLO (Muslimernes Landsorganisation) samt Muslimernes Fællesråd. Styrken ved fremstillingen er, at forfatteren går dybere ind i nogle af de mange uoverensstemmelser, der faktisk har været og fortsat er mellem de pågældende 

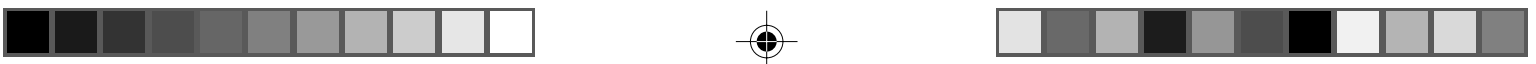

foreninger, når det gælder religiøse fortolkninger, samt hvordan de hver især ser deres rolle og opgave i forhold til det omgivende samfund. Disse uoverensstemmelser giver Schmidt et menneskeligt ansigt ved blandt andet at gå tæt på biografi og religiøst ståsted hos to af miljøets centrale figurer, Fatih Alev og Sherin Khankan.

Det følgende afsnit koncentrerer sig om den samfundsdebat, som aktive danske muslimer på én gang er del af, men samtidig også omdrejningspunkt for (det er jo 'dem', der tales om). I forsøg på at overskride fasttømrede dikotomier mellem majoritet og minoritet eller 'os' og 'dem' lægger Schmidt snittet anderledes. Ved at optegne fire positioner i samfundsdebatten, de henholdsvis islam-skeptiske, islam-inkluderende, ideologisk anti-islamiske og ideologiske islamister, sigter forfatteren mod en optik, der kan overskride dikotomierne. Det lykkes imidlertid kun delvist.

Via citater fra debatten sættes de islam-skeptiske og de islam-inkluderende op mod hinanden. I begge lejre er debattørerne, ifølge forfatteren, kendetegnet ved at være veluddannede, politisk aktive, ofte involveret i humanistiske eller samfundsfaglige forskningsmiljøer og generelt engagerede i den offentlige debat. De to positioner divergerer imidlertid i deres syn på islam og på, hvorvidt denne religion er forenelig med det danske samfund og demokrati. Det andet oppositionspar udgøres af henholdsvis den ideologiske anti-islam og den ideologiske islamisme. Dette er en konfrontation mellem nationalkristne synspunkter, blandt andet repræsenteret ved Dansk Folkeparti, over for anti-vestlig retorik, som den formuleres af blandt andet Hizb ut-Tharir-sympatisører. Ret interessant finder forfatteren, at de to sidstnævnte ekstreme positioner er påfaldende ens i deres retoriske figurer og forestillingsunivers (s. 114).

Så vidt fungerer Schmidts opdeling. Problemet er imidlertid, at de unge aktive foreningsmedlemmer, som hendes bog primært omhandler, er svære at passe ind, idet muslimer primært er repræsenteret som yderligtgående ideologiske fundamentalister. Der er således hverken levnet plads til hovedparten af de foreningsaktive unge eller for den sags skyld til flertallet af de mere end 200.000 muslimer i Danmark, for hvem religion spiller en lille eller slet ingen rolle i deres hverdag. Garbi Schmidts rekonfigurering af samfundsdebatten bliver derfor overvejende til en debat om debatten om 'de andre' - selv om hendes ambition var en anden.

I det sidste afsnit diskuterer Schmidt de transnationale relationer, som hendes unge samtalepartnere (informanter) måtte have. Det er her, man som læser forventer at nå frem til den „Muhammad-krise“, der er nævnt i bogens undertitel. Ens forventninger skuffes imidlertid, da denne lokale og globale begivenhed blot omtales på de sidste to sider. Man kunne have ønsket, at den lovende optakt fra de forudgående kapitler var blevet fulgt til dørs af en mere tilbundsgående diskussion af 

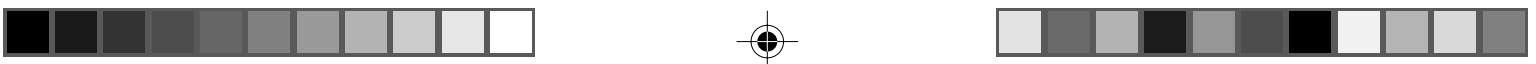

krisen og af foreningernes forskellige roller og positioner i forløbet, der fulgte, men det har der altså ikke været tid eller plads til i denne ombæring.

Det skurrer dog i øjne og ører på en 'islam-inkluderende' forsker som undertegnede, når Schmidt konsekvent anvender betegnelsen „Muhammad-krisen“. Var hun vendt tilbage til de respektive foreninger og aktive muslimer, der medvirker $i$ hendes undersøgelse, ville de givet, mere eller mindre samstemmende, have forklaret, at der på ingen måde var tale om en krise vedrørende islams ufejlbarlige profet Muhammad, men alene en krise afledt af nogle karikaturer i en avis. Det ville følgelig have været $\mathrm{i}$ hendes informanters ånd at betegne det som 'karikaturkrisen'.

Samlet er bogen et relevant bidrag til forskningen i islam, muslimske miljøer og deres mangeartede fremtrædelsesformer i Danmark. Fremstillingen er dog begrænset af sin metode, idet det nu en gang er de aktive velformulerede religiøse talskvinder og -mænd, der primært fokuseres på og som kommer til orde. Det kunne have været interessant at høre mere om de aktiviteter og diskussioner, der udspiller sig blandt menige medlemmer af foreningerne, når de ikke er i offentlighedens søgelys. Som forfatteren selv påpeger, er der mere at komme efter: „Vi ser islam i de offentlige rum, som vi selv færdes i. Men bag ved disse er der rum, som vi kender langt mindre til, og som vi kan være forundrede over findes" (s. 49). En fremtidig opgave for forskere, heriblandt antropologer, bliver at studere og analysere disse mere private rum, som vi må antage findes, men som vi endnu ikke har set særligt mange beskrivelser fra. For de, der tager handsken op og kaster sig ud i denne type projekter, er Garbi Schmidts bog et rigtig godt sted at danne sig et overblik over, hvad der rører sig i feltet af islamfortolkninger og muslimske foreninger i Danmark.

Mikkel Rytter

Ph.d.-stipendiat

Institut for Antropologi

Kobenhavns Universitet

\section{DR2 Temaaften den 1. 9. 2007 om Tranquebar}

Man skulle egentlig være taknemmelig, når de gamle danske koloniale tropebesiddelser overhovedet bliver omtalt, for i lange perioder har de været forbigået $\mathrm{i}$ tavshed, hvilket er blevet begrundet med deres ringe betydning for den nationale selvudvikling. Med tv-serien „Slavernes Slægt“, og Nationalmuseets udstilling „På sporet af Congo“" er der imidlertid opstået en interesse for de glemte kolonieventyr. En hel aften på DR2 giver god plads til at komme omkring det udvalgte emne med nuanceringer og kritisk refleksion, hvis man vælger den vej. 